\title{
To lead or not to lead: regional powers and regional leadership
}

\author{
Detlef Nolte $^{1}$ (D) . Luis L. Schenoni ${ }^{2}$ (D)
}

Accepted: 5 October 2021

(C) The Author(s) 2021

\begin{abstract}
Recent trends demonstrate that states with sufficient capabilities to be granted regional power status by its peers (primarily other states within their region) can nonetheless renounce regional leadership. This article analyzes the puzzling behavior of these detached or reluctant regional powers. We argue that resorting to an approach grounded in neoclassical realism is helpful to explain why regional powers might not exercise leadership. In this article regional leadership is conceptualized as an auxiliary goal within the grand strategy of a regional power. This goal will be pursued in the absence of certain structural and domestic constraints. Great power competition determines the incentives for regional leadership at the structural level. Capacity to extract and mobilize resources for foreign policy affects the decision to pursue leadership at the domestic level. We apply the analytical framework to analyze Brazil's detachment from South America after the Cardoso and Lula presidencies.
\end{abstract}

Keywords Regional powers $\cdot$ Brazil $\cdot$ Status $\cdot$ Hierarchy $\cdot$ Role theory $\cdot$ Neoclassical realism

\section{Introduction}

As we enter the third decade of the twenty-first century, the wave of excitement with the regional powers research program (RPRP) has tailed off (see Frazier and Prys-Hansen, this issue) partly due to its deficiencies to explain all facets of regional power behavior and to capture how regional powers are influenced by domestic and

Detlef Nolte

detlef.nolte@giga-hamburg.de

Luis L. Schenoni

luis.schenoni@ucl.ac.uk

1 German Institute for Global and Area Studies (GIGA), Neuer Jungfernstieg 21, 20354 Hamburg, Germany

2 Department of Political Science, University College London, London, UK 
global dynamics (see Garzon, this issue). Featuring prominently among the phenomena unexplained by the RPRP is the behavior of regional powers that used to perform as regional leaders and have now become increasingly reluctant to lead, ${ }^{1}$ and detached from their regions. ${ }^{2}$ Brazil provides perhaps the most prominent example of this full about-face in the foreign policy of regional powers. In this article, we refer to Brazil as an "ideal type" which presents both an extreme case in our dependent variable of interest (i.e., detachment) and acts as a "pathway case," illustrating the causal mechanisms leading to it (Goertz 2017: 259).

From the standpoint of both theory-based predictions and historical records, the phenomenon of detachment is singularly puzzling. Regional powers traditionally exploited the size and resource gap with their neighbors to project themselves as regional leaders and, by extension, global players. If the capacity gap persists, as does the disposition of neighbors to follow, prevailing scholarship would expect incentives to exercise leadership on the part of regional powers to remain high, despites the various challenges of this strategy (see Hurrell 2006). So, why are regional powers renouncing leadership unilaterally as of late? How can it be, for example, that successive Brazilian presidencies covering the whole of the ideological spectrum-from Dilma Rousseff (2011-2016) to Michel Temer (2016-2019), and now Jair Bolsonaro (2019-) — have jettisoned the successful diplomatic efforts during the Fernando Henrique Cardoso (1995-2003) and Luiz Inácio "Lula" da Silva (2003-2011) administrations to convince other South American countries to follow Brazil?

The phenomenon of regional power detachment obviously transcends recent developments in Brazil. Thus, to answer this question at a theoretical level, some conceptual clarifications are necessary. As we will show in the following sections, some scholars might question whether a state should be considered a regional power if it completely forsakes leadership. Thus, the first thing that we advocate is to differentiate clearly between the status of a regional power, the pursuance of regional leadership as a goal and its exercise as a role. The concept of regional power refers to a superiority in capabilities, which is at least implicitly recognized by other states in and beyond a region as structurally determining a regional power's higher social standing. Such status can generate the expectation of leadership and facilitate its exercise but is analytically distinct from it. The conceptualization of regional leadership as a goal regional powers can pursue-rather than a role they are enactingis key to answer our main research question: under which conditions will regional powers renounce (or bid for) regional leadership?

We argue that a state with regional power status might strive for regional leadership as an auxiliary goal within the context of its overarching foreign policy strategy.

\footnotetext{
1 See Destradi on the concept of reluctance in IR: "To capture a particular way or style of foreign policy —one entailing hesitation and, at the same time, a recalcitrant attitude vis-a-vis the expectations articulated by others" (2017: 334).

2 Prys (2010: 489) introduced the concept of "detached regional powers", which are "induced either by insufficient resources or, for instance, by a lack of identification with the region." Arguing that "such an actor will focus largely on domestic and/or on global politics, instead of on its regional role."
} 
Yet, specific situations might arise where regional leadership will not be perceived as a desirable goal. Our explanation considers a combination of structural and domestic factors affecting the cost-benefit analysis of regional powers. First, restrictive international environments will stymie regional leadership by making great powers wary of regional powers, preventing delegation of functions, and making leadership a more costly strategy overall. Second, adverse domestic developments such as economic crises and corruption scandals can affect the capacity of the government to extract and mobilize resources for regional leadership. Foreign policy shifts from leadership to detachment, thus, will result from the combination of these international and domestic constraints. As we demonstrate bellow, neither structural nor domestic factors, when considered alone, can explain the outcome. A neoclassical realistic approach that "adds explanatory power to a structural realist skeleton by incorporating domestic political processes" (Ripsman et al 2016: 31) will be particularly suitable to theorize their interaction. As a corollary, this paper proposes to bring neoclassical realism back into the RPRP.

We divide the remainder of this article as follows. First, we develop a conceptual framework by clearly differentiating the concept of regional power from that of regional leadership and clarifying the distinction between the strategic (as a goal) and the relational (as a role) aspects of regional leadership. Second, we develop a neoclassical realist approach of detachment considering the specific interaction of domestic and international factors that lead to those outcomes. Finally, we explore the explanatory power of our analytical framework with the case of Brazil, a state that pursued regional leadership consistently and tenaciously for almost two decades only to become the main paradigm of regional detachment in the last decade or so.

\section{Regional power as a status category}

Which are the constitutive elements that define a regional power? Two elements are "uncontested in the literature" (Destradi 2010: 905): belonging to a region, and having a larger share of the region's capabilities when compared to second-tier states (see Schenoni 2017). In such situations, regional power status is usually recognized, more or less explicitly, by other states in the region and beyond. States with a greater share of a region's capabilities will always be taken into special account because of the differential impact they might have on that region. But recognizing the importance of a neighbor is different from following its leadership. ${ }^{3}$ Actively undermining a regional power's leadership claim by balancing against it can also evidence status recognition by its neighbors.

Previous conceptualizations have mixed up these distinct analytical dimensions of regional power(hood) (for the concept see Prys 2010) and regional leadership. For

\footnotetext{
${ }^{3}$ Leadership implies a specific use of that power to coordinate other states. For John Ikenberry, for example: "Leadership is the use of power to orchestrate the actions of a group toward a collective end" (1996: 388). See the categorization of different types of regional leadership by Destradi (2010); Frazier and Stewart-Ingersoll (2010); Mitchell (2016); Prys (2010); and Wigell (2016).
} 
example, Nolte (2010: 893) had defined regional power "as a state which articulates the pretension (self-conception) of a leading position in a region that is geographically, economically and political-ideationally delimited; which displays the material (military, economic, demographic), organizational (political) and ideological resources for regional power projection; which truly has great influence in regional affairs (activities and results)." In this and similar definitions the expectation exists that a regional power will "exercise some kind of influence on the region" (Destradi 2010: 905) or be a "regional leading state" (Braveboy-Wagner 2016: 12).

The equation of regional power(hood) and regional leadership has become even more pronounced by the conceptualization of "regional power(hood)/regional leader(ship)" as a role (Guimarães and Maitino 2019; Wehner and Nolte 2017; Wehner 2015). ${ }^{4}$ From the perspective of role theory regional powers are "natural leaders" (Guimarães and Maitino 2019: 8) because their "master role"5 requires the performance of auxiliary roles that imply leadership — as for example, mediator, coordinator, security provider, etc. ${ }^{6}$ Regional powers may be "hesitant leaders" (Guimarães and Maitino 2019, 8) but they need to be leaders nonetheless.

By equating role with status or "master status," defined "as a role that is salient in every situation" (Thies and Nieman $(2018,402)$, role theory subsumes sociological concepts like class and status (see Schulz 2019) - i.e., forms of social stratification that do not necessarily require the performance of a particular role. We argue that status generates the expectation of a certain behavior-e.g., we might expect regional powers to be regional leaders - but social actors do not lose their status if they fail to perform.

We adopt a "positional approach" in contrast to a "relational approach" (see, for example, Duque 2018) to determine the status within a hierarchy. Our concept of regional power ultimately relies on the distribution of power resources-as valued attributes of states ${ }^{7}$ - within a socially constructed region. This distribution of power capabilities always — explicitly or implicitly_define regional hierarchies and the status of states within these. Status is awarded to a regional power by other states in and outside the region-the "status community" (Renshon 2016) or "circle of recognition" (Wohlforth et al. 2017)—by the recognition of its superior power capabilities. Womack condenses this line of argumentation best by stating: "A regional power becomes the regional center of attention because smaller polities have more

\footnotetext{
${ }^{4}$ For example, Thies and Nieman (2018: 31) describe a regional power as "a subset of the major member status that refers to states with higher capabilities than most of their regional peers; those capabilities are thought to imbue such states with special responsibility for the management of the regional order" which includes "socializing novice and minor members in their geographical subsystem."

${ }^{5}$ Even those who debate whether regional power(hood) should be seen as a master role that is salient in every social situation (Thies 2001; Thies and Nieman 2018: 30) still think of it as an auxiliary role within a broader role set. For Thies and Nieman (2018: 69) the role set of Brazil includes at least four regional roles: "regional leader, consensual hegemon, regional power, and regional crisis manager."

${ }^{6}$ Building on Wehner (2015) for Thies and Sari (2018: 402) the recognition of the role of a country "requires the social recognition by other actors of the auxiliary roles" of that country.

${ }^{7}$ Larson et al. (2014: 7) define status "as a collective belief about a given state's ranking on valued attributes (wealth, coercive capabilities, culture, demographic position, sociopolitical organization, and diplomatic clout)."
} 
exposure to it than vice versa" $(2016: 126) .{ }^{8}$ Thus the status as a regional power-or regional powerhood (Prys 2010) - is defined both by the power capabilities (or status resources ${ }^{9}$ ) and by the recognition of these (status recognition) in the de facto activities of other states. ${ }^{10}$

\section{From regional power to regional leader: a neoclassical realist perspective}

So far, we have made the case that the concept of regional power corresponds not to a role states play but to a status position. We also argued that regional powerhood does not presuppose the exercise of leadership. A regional power's attempt to lead can be actively contested by its neighboring states - as it happened historically with Brazil (Malamud 2011; Schenoni 2017) — and yet the latter can still consider the former state to be a regional power. This type of negative recognition of a state's material primacy is corroborated when states coordinate for balancing.

Nevertheless, the "structural leadership" 11 of a regional power facilitates the exercise of regional leadership when this state perceives an opportunity and wants to use his social standing and material resources for that purpose. In this regard, we agree with Underdal's (1994) distinction between "potential" and "actual" leadership. ${ }^{12}$ A decade ago, the RPRP emphasized "leadership must be accepted by followers" as a "necessary condition" for its existence, and asked "under which conditions do potential followers support emerging power's bid for leadership?" (Schirm 2010: 199). Ten years later we might need to take a step back and emphasize a second necessary condition: that also leadership must be sought by prospective leaders for it to take place. Both push and pull factors are necessary.

If we agree that leadership is not socially imposed upon regional powers but rather requested, and that their decision to "play the role" is ultimately and

\footnotetext{
8 One might call this also the "systemic impact" — within the regional subsystem-of the regional power. For a conceptualization of the systemic impact of middle powers, see Carr (2014).

9 "Understood as a state's cumulative potential for social action that could generate status recognition for a state" (Røren and Beaumont, 2019, 434).

10 How to measure status recognition? In a classic text Singer and Small (1966) proposed diplomatic exchange-i.e., the number of diplomatic offices that a country had-as a measure of status ordering. In his study of hierarchy and authority, Lake (2007) proposed state visits as a traditional form of status recognition. Cline et al. (2011) continue to ascertain the status of a regional power by the number of state visits and diplomatic contacts at both the regional and the global level. Yet, diplomatic representatione.g., the number (or network) of embassies - continues to be the most standard measure for status recognition (see Duque 2018; Renshon 2016; Røren and Beaumont 2019). Mitchell (2016) proposes as one element in differentiating between regional powers the centrality of the regional power in the foreign policy of other states in the region which might be also interpreted as an indicator of regional status. Social network analysis might be another option to identify the position / status of states within a region.

11 "Structural leadership refers to the underlying distribution of material capabilities that gives some states the ability to direct the overall shape of world political order" (Ikenberry 1996, 389).

12 "Leadership actually supplied by an actor can most simply be conceived of as a function of two major determinants: capabilities and structural positions, constituting sources of potential influence; and behavior which more or less effectively transforms potential into actual leadership" (Underdal 1994, 181-182).
} 
fundamentally a goal they must choose to pursue, a neoclassical realist approach might prove useful to explain why certain regional powers strive to lead, while other do not. In the end, neoclassical realism is usually conceived as a theory of grand strategic choice (Ripsman et al 2016: 2; see also Kitchen 2010), and by considering international (demand) and domestic (supply) factors simultaneously, it already suggests the individual necessity and joint sufficiency of conditions at both levels.

The concept of grand strategy is particularly useful to illuminate the greater degree of agency that regional powers have in this story. Kitchen $(2010,211)$ defines a grand strategy as an analytical concept which refers "to a set of national policies in peace and war that both set out the goals of the state in international politics and prescribe how a broad range of national resources should be utilized in pursuit of those goals." He differentiates between three elements for the formation of a grand strategy "(1) the identification of threats to the security of the state; (2) the selection of means to address identified threats, and (3) the identification of auxiliary goals and the selection of the appropriate means to attain them (Kitchen 2010: 134-136). Regional leadership, in this sense, could be understood as one of many auxiliary goals in the grand strategy of regional powers-presumably one of ascension to the rank of great power at most, and one of securing survival in turbulent times, at the very least.

When regional leadership becomes part of the grand strategy of a regional power, role theory becomes an important analytical tool for studying the exercise (and possible limitations) of leadership. In the case that a regional power claims leadership, the question of how leadership becomes accepted by secondary powers (Wehner 2015) and minor powers (Guimarães and Maitino 2019) is an interesting research question where role theory can provide important insights. But, as we have argued, role theory is less helpful to analyze the behavior of regional powers that are not interested in regional leadership as a goal within their grand strategy.

Neoclassical realism seems much better suited to capture situations where "the scope of a state's auxiliary goals will be constrained by the availability of resources" (Kitchen 2010: 136). Understood in this way, the option of regional leadership is restricted by the interplay of factors at the system level (international) and at the unit level (the state) that influence the grand strategy of a regional power. This fresh perspective on the behavior of regional powers serves to unblock several aspects of the RPRP this special issue is concerned about. It gives more room to internationalsystemic factors as claimed by Garzón (in this special issue) and it includes the domestic support and capabilities for external power projection (as claimed in the introduction by Frazier and Prys-Hansen).

\section{Systemic stimuli: the international structure}

While the status of regional power refers to the relative position of a state vis-àvis its neighbors, a regional power is also part of the larger international system where regional leadership is supposed to take place. In this broader context, a regional power might be a small power, a middle power, or a great power. Regional 
powers' capacity to lead is depending on this global positioning, and how great power dynamics affect opportunities for subaltern leadership.

Structural factors at the regional or sub-systemic level include the aggregated capabilities of the region itself and the number of regional powers (or strong secondary powers) within it. Leadership will be less costly for regional powers in smaller regions and facing no peer competitors. ${ }^{13}$ As a general rule, the smaller and more fragmented a region is, the easier it should be for any single state to become a regional power. But a small region can also turn leadership less appealing, while the presence of regional rivals can provide incentives to invest in leadership (regardless of the size of the region). Important as they are, these cost-benefit calculations at the regional level are necessarily subordinate to other, systemic factors.

Scholars have long argued about the ways in which the distribution of capabilities among the great powers-i.e., polarity-affects regional dynamics. For Huntington (1999) a unipolar structure naturally lends itself to regional leadership, as regional powers want to promote a multipolar distribution of functions, and the unipole will consent if this lends legitimacy to the status quo and helps preserve it. The period characterized by Huntington (1999) as a uni-multipolar system ${ }^{14}$ was therefore particularly favorable for regional powers exercising regional leadership. Most theorists of unipolarity would agree that the predominance of one great power will give regional powers more leeway in their regions (Wohlforth 1999; Walt 2009) —a prediction that is also in line with hegemonic stability theory (Gilpin 1981: 242).

Under bipolar contexts-where balance of power takes precedence over hierarchical stratification and division of labor-both theory and the Cold War experience predict a low incidence of regional leadership. Kenneth Waltz himself explicitly laid out the many reasons for this. Bipolarities offer a duopoly to great powers, who unlike in multipolar contexts, can easily negotiate, agree with, and monitor each other. Bipoles will appreciate these benefits and exclude third actors that might threaten to tilt their balance (Waltz 1979: 135, 169, 194). They are also likely to agree on spheres of influence and become the sole leaders of rigid coalitions, obliging regional powers to align with them and leave the spotlight (Waltz 1979: 163). Finally, because each great power will be wary of the relative gains obtained by the other, great powers in a bipolar setting are likely to overreact and directly intervene in peripheral crises, sidelining regional leaders (Waltz 1979: 172). The lack of research on regional powers during the Cold War era seems to corroborate Waltz's prediction. Similarly, the current reluctant behavior of many regional powers conspicuously matches the emergence of a new international structure featuring the USA and China as bipoles.

\footnotetext{
13 South Africa and Nigeria are perhaps the clearest examples of minor states that have acquired regional power status due to the even smaller size of their neighbors and the absence of any immediate competitors. Their GDP is one-seventh that of Brazil, yet they are unipoles-i.e., they more than triple the size of the next biggest economy in their regions (Schenoni 2017).

14 It is less clear how "pure" forms of multipolarity would affect regional leadership, since these have not been very common in recent historical record. Garzón (2017) proposes that under "decentered multipolarity" regions might become more porous, regional powers become ineffective power reflectors, and the exercise of regional leadership becomes more difficult and cost intensive.
} 
The agency of great powers - both in promoting and opposing regional leadership - is even more relevant in regions where they are encroached. In these cases, great powers can easily boost regional leadership or persuade a regional power to act with more restraint. If wary of a regional power's intention, great powers may form alliances with minor or secondary powers in the region (Wohlforth 1999: 31). All in all, as succinctly formulated by Womack (2016:126): "The basic dilemma of all regional powers is that they are in the default position of leadership in their region, but their region does not delimit the alternatives of its members."

Of course, there are many other international factors that might foster or hinder regional leadership in particular cases. By focusing on the international structure and the great powers we do not mean that other factors are always irrelevant. We contend, however, that other international factors are subordinate to structural constraints, either because they are epiphenomenal-i.e., they are caused by them-or because their causal impact is less important. ${ }^{15}$

\section{Domestic constraints: state mobilization capacity and grand strategy}

By answering the question of "how the structural pressures of power in the international system are translated into foreign policy outcomes by states" (Kitchen $2010 ; 119)$, neoclassical realism offers concepts that can be applied to the analysis of the relationship between systemic stimuli (for action), power resources, and the foreign policy outreach of regional powers. To capture the link between the power resources of a state and the capacity to effectively make use of them, for example, Volgy and Bailin (2003) introduced the concept of "domestic strength", ${ }^{16}$ Schweller (2006: 13) that of "state mobilization capacity", ${ }^{17}$ and Zakaria (1998) the concept

\footnotetext{
15 The disposition to follow by other states in the region is likely to affect the willingness to lead on the part of a regional power (Malamud 2011). Detachment might be also caused by a lack of regional ideational affinity in the view of the regional power, which may lead to engagement in global rather than regional organizations (Hofmann et al. 2016). Conflicts inside or between states within the region might provide opportunities for a regional power to exercise leadership with the objective to bring order to the region, although too much conflict can also lead to a detachment from a troublesome regional context. While all these dynamics might be important, we argue they are rather secondary in explaining why regional powers choose to lead when compared to systemic stimuli. We also adopt a view of systemic stimuli fundamentally based on the power distribution between states (geopolitical), instead of one based on capital and trade flows (geoeconomics) assuming the theoretical precedence of the former. Thus, economic dynamics pulling Brazil outside its region (Scholvin and Malamud 2020) would be a further expression of overarching changes in power relations for us.

16 "First, the state has available to it substantial resources (its extractive capability from its economy) that can be transferred to foreign activities. Second, such resources are not severely constrained by domestic needs and priorities. Third, those who command the apparatus of the central government are politically strong enough to effectuate transfers to foreign activities if such transfers become necessary" (Volgy and Bailin 2003: 42). In a more recent study Volgy et al. (2017) substitute "domestic strength" with "domestic political competence," which refers to the ability to develop and implement effective strategies for creating a regional order.

17 The intellectual history of this idea in IR can be probably traced back to the concept of "usable power" defined as the domestic political capacity to translate power assets into international influence (Hoffmann 1978: 474; Trubowitz and Harris 2019), and beyond that, in the literature on state capacity where it can be equated to the idea of "infrastructural power" (Mann 1984: 187). A literature review should also mention a mayor project of the RAND Corporation in the early years of the new century
} 
of "state strength." 18 This aspect is not taken systematically into account in analyses of regional leadership, ${ }^{19}$ despite the existence of an extensive literature highlighting the deficits of regional powers. Deficits which could hinder the mobilization of their power capabilities. ${ }^{20}$

The aforementioned concepts of state power or state strength point to the fact that, due to domestic constraints, many regional powers-or more precisely the statesmen ${ }^{21}$ of regional powers-might not be able to exercise regional leadership, even if wanting to, so long as they lack the capacity to extract or mobilize sufficient resources from their societies. ${ }^{22}$ Several factors can affect the ability to convert power resources-as measured by conventional indicators such as GDP, military strength -into effective foreign policies.

Resource extraction capacity - in the form of taxation or recruitment for bureaucratic offices, for example — can be limited by the lack of organizational capacity (efficient institutions, trained cadres, etc.). Economic crises reduce the tax base of any society, affecting the available resources that can be extracted for foreign policy. From this perspective, Fukuyama (2014) argues that political systems might translate power resources into effective foreign policies only at "a kind of discount rate" which might reduce a government's leadership capacity and ambitions.

Moreover, the mobilization of resources already extracted from society for foreign policy activities can be severely constrained by the same factors mentioned before and others, such as governmental crises or instability, lack of political leadership, an inefficient bureaucracy, the encroachment of interest groups within the state, a manifest disinterest in foreign policy on the part of authorities, or an adverse

\section{Footnote 17 (continued)}

(Tellis et al. 2001; Treverton 2005), one with the objective of measuring national power, which differentiated between "national resources" and "national performance." This line of reasoning has been followed by neoclassical realists (Taliaferro 2009; Ripsman et al. 2016).

18 For Zakaria (1998: 38) "state power is a function of national power and state strength." The state structure imposes a discount on national power. Ergo "the weaker the state, the bigger the discount" (Zakaria 1998: 188).

19 But there are exceptions. In their comparative study of Mexico and Brazil Chagas Bastos and Franzoni (2019: 37) use the concept of "domestic agency" arguing that "one should examine not only a states' material capacities - the structural determinants-but also the interaction between its national policy context and the design of domestic policies toward abroad." Schenoni (2012) had already pointed to the importance of domestic institutions in allowing the performance of a leadership role by Brazil; a decade before, in her conceptualization of emerging middle powers, Schoeman (2003: 353) also argued that "the internal dynamics of such a state should allow it to play a leading role in its region."

20 As for Nigeria and South Africa, as early as 2003 they would be described as "giants with clay feet" (Adebajo and Landsberg 2003: 191) due to their many domestic challenges. Similarly, with regard to Nigeria Ogunnubi, Onapajo, and Isike (2017: 2) argue: "The lack of sustained internal cohesion evident in the continued strife is stifling Nigeria's claims as an African leader and regional power." Alden and Schoeman (2015: 240) refer to South Africa's limited ability to translate preponderance into foreign policy and economic gains as well.

21 "Statesmen, not nations, confront the international system and they have access to only a fraction of national power that the state apparatus can extract for its purpose" (Zakaria 1998: 35).

22 Another reason for adopting a neoclassical realist framework instead of other theories that combine systemic and domestic factors (e.g., Moravcsik 1997) is our focus on the state and statesmen-instead of societal actors - as the key preference makers. 
public opinion. Ultimately, however, mobilization to pursue a leadership goal is a political decision that implies the abandonment of other, alternative goals.

While concepts such as domestic strength or state mobilization capacities are quite useful for analyzing domestic constrains, they still fail to capture the ideational basis of regional leadership. We have to circle back to the concept of grand strategy to (re)integrate material resources (including state capacity) with foreign policy ideas, and the agency of political leaders. The analysis of the grand strategies of regional powers is the adequate approach to capture the (lack of) strive for regional leadership; because it puts the focus on the strategic decisions by (the leaders) of regional powers to prioritize leading the region within the many other goals in their foreign policy agenda. A decision not to strive for regional leadership can be the result of changes in the domestic economy and politics, including ideational shifts, ${ }^{23}$ which lead to an adjustment in the grand strategy of a regional power.

\section{Brazil: persistent status despite fading leadership}

In Strategies of Rising Brazil: Postmortem Review, Looking Forward, Matias Spektor draws on the concept of "strategic diplomacy" to show that "the boundaries [of Brazilian grand strategy] were not drawn by the international system alone, but they are a conscious choice of those who make foreign policy" (Spektor 2021: 4), reflecting our view of regional leadership as a purposive goal constrained at the same time by international and domestic factors. In this section, we build on his exhaustive review and interpretation of the literature to empirically illustrate our previous theoretical points.

Brazil has pursued regional leadership as an auxiliary goal at least since the second presidency of Fernando Henrique Cardoso (1999-2003), which featured a reorientation of foreign policy from one of "autonomy through distance" to one of "autonomy by engagement" (Burges and Chagas Bastos 2017: 283). The first summit of South American presidents in 2000-which laid the basis for the creation of UNASUR in 2008-is broadly recognized as delimiting the regional scope of such leadership and setting a new tone in the foreign policy community (Spektor 2016: 26). The project was inherited by Luiz Inácio "Lula" da Silva (2003-2011), who used this South American platform to play a leading role in the Doha world trade conference and the United Nations system, pushing Brazil's candidacy for a permanent seat in the Security Council, and becoming a founding member of the BRIC Group in 2009.

The abandonment of regional leadership apparently started in 2011 and developed in three acts. First, Dilma Rousseff (2011-2016) downgraded foreign policy in her government's agenda. Then, Michel Temer (2016-2019) started to question

\footnotetext{
23 Kitchen (2010: 139) argues "Shifts in personnel, institutional power, or the popularity of particular ideas may precipitate changes in goals or encourage reassessment of the means by which to pursue them. Such shifts may be driven from the bottom up, by electoral results or by the use of bureaucratic leverage; or from the top down, in the form of the executive's power of patronage and final decision."
} 
regional leadership as a goal, promoting alternative ones (Kalout and Degaut 2017). Finally, Jair Bolsonaro (2019-), who campaigned openly on detaching from the region, radically abandoned this objective (Stuenkel 2014; Gardini 2016; Burges 2017; Lehmann 2017; Malamud 2017; Vaz 2018; Chagas Bastos and Franzoni 2019; Schenoni et al. 2019).

That the former South American leader has forfeited regional leadership to focus on other issues is hardly debatable. Since at least the presidency of Temer, Brazil has evaded assuming a leading role in important regional processes. Its absence was blatant in the Colombian peace accords (Malamud 2017: 149), and disengagement from the Venezuelan crisis is evident. Brazil promoted the suspension of Venezuela from Mercosur on August 5, 2017, and entered the Lima Group a few days after, actively trying to reframe a South American issue into a matter of Hemispheric concern. Afterward, Bolsonaro's Brazil-first policy has been one of blatant unilateralism. He even withdrew from UNASUR, the institution that epitomized the Brazilian leadership project (Vadell and Giaccaglia 2019), ${ }^{24}$ leading to its demise. Since then, Brazil's regional role has been to scorn and threaten neighbors, while avoiding any sort of involvement in regional crises or the promotion of regional projects.

Moreover, Brazil has been incredibly resistant to the attempts by other states in the region to reclaim its leadership. Although Brazil's acquiescence was key for the creation of PROSUR, its role was that of a follower ${ }^{25}$; despite the expectations of the Lima Group and the Venezuelan opposition, Brazil has also adopted a secondary, reactive role in the Venezuelan crisis. Right-wing allies of Bolsonaro in Chile, Bolivia, and Ecuador, surely missed the days when Lula helped stabilize his leftwing partners. Yet, the Brazilian detachment from the region seems to go beyond the ideological posture of Bolsonaro, and can be traced back to the left-wing government of Dilma Rousseff. This points to the secondary role played by ideology, and the primary importance of the 2011 critical juncture in this process.

Interestingly, however, Brazil has not lost its regional power status. Even after the detachment from the region, the Brazilian state continues to be the eight-hundredpound gorilla in the neighborhood. Bolsonaro has moved like bull in a china shop, causing havoc even unintendedly, keeping diplomacies in South America mesmerized while they try to decipher his next move. But it is not Bolsonaro's style that attracts attention. Rather, it is the sheer size and weight of the state he governs. The broader regional impact of political events and crisis-e.g., regarding the mobilization of regional diplomacy, the involvement of regional organizations, etc.in South American countries ultimately depends on the reactions of the Brazilian

\footnotetext{
${ }^{24}$ In the words of former Brazilian foreign minister Celso Amorim (2014: 111; 2010: 229-230) Unasur was an instrument to project a "South American identity" and to give "South America a face."

25 In January 2019, the Colombian government came out with the idea to create a new South American regional forum substituting UNASUR. This proposal found the support of the Chilean president Sebastian Pinera. Both presidents invited their South American peers to Santiago on March 22 to create the new forum baptized PROSUR (Foro para el Progreso de América del Sur). At the end of the summit the Declaration of Santiago giving live to the new forum was signed by seven South American presidents (Argentina, Brazil, Chile, Colombia, Ecuador, Paraguay, and Peru) and by the ambassador of Guyana in Chile.
} 
government. But not only the government matters. Laws passed by the Brazilian Congress - such as the 2019 Social Security Reform - have notable repercussions in the flow of investment across the region, and the decisions of Brazilian judges tore down the career of political leaders in other countries-most prominently Colombian and Peruvian ex-presidents accused of corruption in relation to Brazilian construction projects abroad. The fact that the actions of the Brazilian bureaucratic and political machinery can still cause shock waves in the region shows that Brazil has retained its regional power status.

Brazil's predominant status can also be corroborated by other (quantitative) indicators. Brazil might not be a global player nor a regional leader anymore, but it still hosts the largest number of consular offices from other South American countries, has the largest number of consulates in South America, and could singlehandedly kill international organizations like UNASUR. With half of the South American's population and GDP, Brazil will preserve its regional power status, regardless of the Brazilian government's foreign policy priorities.

What has changed, is not Brazil's status but its disposition to pursue regional leadership. This, in turn, is not primarily caused by a change in the ideology of the government - as important this factor might be (Merke et al. 2020)—because governments of the (center) right and the left decided to strive for leadership before 2011, and governments of the right and the left have equally become detached from the region afterward. The explanation must be sought in other factors which changed during this critical juncture.

\section{Brazil amidst structural constraints}

If we consider the relative power capabilities of Brazil, both in the regional and international context, only minor changes have taken place since the 1980s. In hindsight, it can be seen that Brazil's "rise" was caused by factors other than the relative increase in Brazilian material resources-e.g., its participation in the regional or global GDP. ${ }^{26}$ Brazil's status as the only South American regional power can be traced back to the end of geostrategic competition with Argentina (Schenoni 2017) and has remained unaffected since then. If that is the case, other (variable) factors must have affected Brazil's propensity to strive for a leadership goal in the CardosoLula era.

While exploring the reasons for "Brazil's international rollback," Malamud (2017) already argued that the polarity of the international system and the degree to which established powers were hostile or friendly to the ambitions of the regional power have been decisive. Yet, we disagree with his sweeping statement-reflecting conventional wisdom-that "ceteris paribus, the more the powers, the more permissive the system" (Malamud 2017: 150). It was rather unipolarity that allowed for

\footnotetext{
${ }^{26}$ While there has been some change regarding the material capabilities within the group of South American secondary powers such as Argentina, Chile, Colombia, and Venezuela (see Flemes and Castro 2016; Schenoni and Escudé 2016), this did not upset the predominant status of Brazil as regional power in any relevant way.
} 
regional leadership and the activism of regional powers which in turn created the illusion of multipolarity.

Since the world has never been really multipolar, Brazil benefited greatly from a permissive context in which only one great power held global primacy. Reliance on regional leaders was a key feature of unipolarity (Huntigton 1999) which became even more pronounced as Washington's grand strategy switched from defensive to offensive dominance (Monteiro 2012). After 9-11 the U.S.A' focus on the Middle East and the fight against terrorism created space for more autonomous South American foreign policies and bolstered Brazilian leadership (Mijares 2018). Thus, despite some occasional skirmishes-e.g., harsh criticisms voiced during the Iraq War-Brazil was seen as a necessary partner to outsource leadership in the region, which is also reflected in the good relations between President Bush and President Lula.

This scenario, however, changed abruptly as Washington started to become preoccupied with the evolution of great power politics. The creation of UNASUR in 2008, and that of the BRIC Group in 2009, already raised some red flags. Yet, the partnership between Ankara and Brasilia to broker a nuclear deal with Tehran in 2010 has been identified as a turning point in the relations between the U.S.A and Brazil $^{27}$ as it caused concern that Brazilian leadership could be playing in the hands of powerful enemies. Ostensibly, however, it was the partnership with Beijing that worried Washington the most, as the world apparently progressed toward a new bipolarity. Instead of trusting Brazil with regional matters the U.S.A has been using a mix of carrots and sticks-e.g., the promise of OECD membership and NATO partnership - to allure Brazil away from China in key issues like its 5G bid. In the meantime, Washington ensured that key regional crises-e.g., Venezuela, the 2019 Bolivian crisis, etc.- - were treated mainly through Inter-American institutions where it can have a strong saying, and openly struggled for a tighter control of hemispheric institutions like the Inter-American Development Bank (Schenoni and Leiva 2021).

Although one might counterargue that Brazil's regional leadership was favored by China's increasing demand for commodities_leading to high economic growth rates-our polarity-centered argument can better explain certain contradictions that pervade this view. First, while commodity rents can explain Brazilian "foreign policy overstretch" during the Lula era (Schenoni et al 2019), it cannot explain preexisting leadership during the Cardoso era-i.e., before the boom. Second, a la longue the commodities boom had also negative effects for Brazilian leadership in the region: it strengthened extra-regional links of neighboring economies (Garzon 2017), diminished Brazil's economic clout within South America, both in the manufacturing sector and as a trade partner (Lima 2018) and decreased its own interest in the region (Schlovin and Malamud 2020). Third, proximity to Beijing eventually backfired as China came closer to achieve the status of a great power, and Washington started a containment policy, with Barack Obama's "pivot to Asia," Donald

\footnotetext{
27 The bold Brazilian move was unprecedented and strongly criticized in Washington. "Brasil e Turquia inisitem em acordo com Irã. Hillary critica atitude” Folha de S. Paulo, 05/27/2010.
} 
Trump's aggressive trade policies, and Joseph Biden's restructuring of strategic partnerships more recently.

Trapped between the military and political clout of the U.S.A and the economic clout of China (Urdinez et al 2016), the Brazilian government opted for a strategy of muddling through by avoiding controversial decisions-for example by delaying the aforementioned $5 \mathrm{G}$ bidding process - and maintaining a low profile by eschewing any regional leadership role that could lead to an entanglement with this all-encompassing geostrategic competition. Detachment, therefore, became a handy strategic device to avoid frictions with the great powers. ${ }^{28}$ Despite sharing a very similar ideology and taking over most of his foreign policy team, "Dilma Rousseff succeeded Lula in 2011 in a domestic and global context that gave her far less leeway to conduct an activist foreign policy" (Spektor, 2016: 21).

\section{The Brazilian loss of foreign policy resources}

As with most other regional powers "a look at Brazilian foreign policy since democratization suggests that activism abroad is only possible if things are in order domestically" (Stuenkel 2019). The economic policies of Cardoso laid the foundations for Brazilian leadership, providing economic stability, a sustainable source of revenue, and diminishing external dependence on foreign creditors. Cardoso increased Brazil's state mobilization capacity by introducing important reforms in Itamaraty (the Ministry of Foreign Affairs) (Faria et al., 2013; Rivarola 2008; Schenoni 2012: 662). Brazil's adoption of a regional leadership role is therefore in line with the maxim that "nations try to expand their political interests abroad when central decision makers perceive a relative increase in state power" (Zakaria 1998: 42).

During the Cardoso and Lula presidencies, Brazil was quite successful in extracting resources for foreign policy. The participation of Itamaraty in the Brazilian budget increased, from an average of 0.6 percent in the 1990 s to 1.3 percent in the 2000s.Diplomats benefited substantively through the increase in salaries and opportunities. From 2002 to 2010 alone, the budget of Itamaraty rose from 0.7 billion to 2.2. billion Reais, the number of diplomatic missions (embassies and consulates) abroad jumped from 150 to 217, and the number of diplomatic posts rose from 997 to 1405 (Schenoni et al 2019). Moreover, the Brazilian government (especially during the Lula presidency) extracted resources from big firms known as campeões nacionais (national champions) which through public credits from the National Bank for Economic and Social Development (BNDES) spearheaded the expansion

\footnotetext{
${ }^{28}$ Great power politics affected Brazilian regional leadership through other, more indirect channels as well. The slow transition away from a world of multilateral trade talks, that opened with the Doha Round, ended up in a far more cumbersome scenario of bilateral and minilateral negotiations that curtailed the leadership opportunities of Brazil in trade issues. Even the United Nations have lost its former relevance in the management of global issues, making regional leadership less necessary in this forum. This seems to be particularly true in the realm of peace and security, rendering the Brazilian quest for a permanent seat in the Security Council a futile goal.
} 
of Brazilian economic interests abroad. ${ }^{29}$ BNDES financed some 140 projects in Africa and Latin America during those years, allowing the national oil company Petrobras to expand its presence to 27 new countries.

Brazil skillfully projected soft power as well. State financed organizations like the Brazilian Cooperation Agency (ABC) increased their participation in development projects abroad by 1,000 percent. Presidential visits abroad have been perhaps the most impressive indicator of activism and resource mobilization. They averaged 15 per year in the Cardoso era, and 27 per year with Lula, usually including an entourage of hundreds of diplomats and businessmen (Schenoni et al 2019).

The beginning of Dilma Rousseff's government marks a major critical juncture in Brazilian resource extraction and mobilization capacity for foreign policy making (Cervo and Lessa 2014). A sharp decline in GPD growth in 2011 already led to fiscal cuts which affected most activities of Itamaraty, from multilateral cooperation to participation in peace keeping operations (Schenoni et al 2019). The following second worst recession in Brazilian history coincided with a huge corruption scandal which triggered a chain of dramatic events that led to the impeachment of Rousseff in 2016 and afterward to the election of a populist and isolationist president.

The economic crisis led to fiscal constraints with a direct impact on Brazilian's regional leadership options. After the diplomatic budget had plunged in 2011, embassies all over the world adjusted to subsistence levels, and diplomats went on strike to have their rents paid. Brazil's outstanding contributions left the country on the brink of suspension from international organizations like the International Criminal Court, and many other bodies within the United Nations system. This evidence corroborates the decline in Brazil's capacity to extract and mobilize resources in order to put its foreign policy to work, let alone to lead the region..$^{30}$ During Dilma's presidency the Brazilian government also "lost" important domestic partners for executing foreign policies such as Petrobras and Odebrecht which retracted in the context of Operation Car Wash-by far the major corruption investigation in Brazilian history (Lehmann 2017: 135). Criminal investigations involved at least 16 Brazilian companies and their activities in 49 countries, and a remarkable part of the fiscal deficit was caused by cheap credits from the BNDES (Zanini 2017).

The crisis had a collateral effect on the domestic backing for a regional leadership project. After a decade of increasing support for Brazilian leadership (Almeida et al., 2010,32 ), in the aftermath of the crisis, international adventurism became a synonym for corruption and fiscal irresponsibility. A recent survey in Brazil (Guimarães

\footnotetext{
${ }^{29}$ Credits from the BNDES expanded considerably since 2001, from 6 billion Reais to an average of 21 billion between the years 2009 and 2014. The impressive increase in BNDES credits focused particularly on the outward-oriented construction and energy sectors, 75 percent of these credits went to big companies, and by 2010, around 60 percent ended up being invested abroad. Credits to these two sectors expanded nominally by 1,000 and 2,000 percent, respectively. Controlling for GDP growth, state support for foreign investment quadrupled during the period (Schenoni et al 2019). Brazil also increased its capital participation in the CAF Development Bank of Latin America and thus issued credit for foreign ventures through other channels as well (Burges 2018).

30 The decline in Brazilian foreign policy activities confirms Zakaria's (1998: 42) dictum: "Statesmen can exploit the power resources of their nation only as transmitted through the state structure: foreign policy is thus the product of state power."
} 
et al. 2020: 114) exposes that "the public tends to reject regional leadership, choosing instead options in which Brazil does not act as a leader"; a decline in support for regional activism that was already evident in other studies (see Onuki et al 2016). Although this would not have been a problem for an authoritarian Brazil, the democratization of foreign policy and its prominence as an electoral topic became two strong institutional channels-powerful intervening variables in neoclassical realist theory (Ripsman et al 2016: 76)—influencing its regional leadership strategy.

Finally, changes in the presidency have been the catalysts of foreign policy change and the demise of regional leadership as a foreign policy goal. The president is the "articulator of Brazilian foreign policy" (Lehmann 2017); and as Burges and Chagas Bastos (2017: 278) argue "direct and sustained presidential engagement (...) drives change and innovation in Brazilian foreign policy." Both Cardoso and Lula were successful "to translate long-standing principles of Brazilian foreign policy into practical policies for their respective circumstances” (Lehmann 2017: 132). This changed with Rousseff and Temer, who neither showed the same interest in foreign policy, nor developed a strategic vision. Bolsonaro, on the contrary, more clearly articulates that regional leadership is not an auxiliary goal in Brazil's grand strategy which does not mean that Brazil is not paying close attention to what is happening in its neighborhood. But it is not any longer really engaged with its region, the foreign policy has become outward oriented with a focus on the U.S.A, China, and Europe.

\section{Conclusions}

The quest for regional leadership of states such as Brazil fueled the study of regional powers. But Brazil as a former poster child of the RPRP also reveals shortcomings in the research approach and exposes an understudied phenomenon, as regional powers have become less interested in exercising leadership. The objective of this article is to make some basic conceptual clarifications regarding regional powers and regional leadership, and to develop an analytical framework to explain the decline or lack of interest of regional powers for regional leadership.

In a first step, this article proposes to distinguish more clearly between the status of a regional power, the strive for leadership - which presupposes regional leadership as a goal-, and the effective exercise of regional leadership, which requires followers to altercast a leadership role. This conceptual differentiation opens the possibility of a non-leading regional power because regional leadership is a foreign policy goal that can but does not have to be pursued without affecting the status of regional power.

Our neoclassical realist approach-which conceptualizes regional leadership as an auxiliary goal within the grand strategy of a regional power-focuses then on domestic and systemic constraints affecting the propensity toward adopting this auxiliary goal. Undervalued in the heydays of regional powers research, neoclassical realism provides a persuasive framework to explain detachment. From this perspective both the constraints of the international system-mostly, but not only, defined by polarity - and domestic limitations of a state's extraction and mobilization 
capacity (for foreign policy) can dissuade a regional power from striving for regional leadership.

As the illustrative case of Brazil's rise (and detachment) as regional power demonstrates, regional leadership has been favored and facilitated by U.S. delegation and neglect under unipolarity, and later undercut by increasing U.S. geostrategic concerns as the world entered the current bipolar scenario. Moreover, the leadership turnaround of Brazil demonstrates that domestic constraints matter for exercising regional leadership. By focusing on how structural pressures (or incentives) in the international system are translated into foreign policy outcomes, neoclassical realism gives enough consideration to the domestic impediments of regional powers. The fate of several once hyped regional powers (Brazil, Nigeria, and South Africa) points to the need to include more systematically the domestic and systemic constraints for exercising leadership. Paraphrasing Mark Twain, we believe the reports that the concept of regional power has led to a dead end (Gardini 2016: 14) are exaggerated. More conceptual clarity and theoretical openness in different directions can still save this research agenda.

Funding Open Access funding enabled and organized by Projekt DEAL.

\section{Declarations}

Conflict of interest On behalf of all authors, the corresponding author states that there is no conflict of interest.

Open Access This article is licensed under a Creative Commons Attribution 4.0 International License, which permits use, sharing, adaptation, distribution and reproduction in any medium or format, as long as you give appropriate credit to the original author(s) and the source, provide a link to the Creative Commons licence, and indicate if changes were made. The images or other third party material in this article are included in the article's Creative Commons licence, unless indicated otherwise in a credit line to the material. If material is not included in the article's Creative Commons licence and your intended use is not permitted by statutory regulation or exceeds the permitted use, you will need to obtain permission directly from the copyright holder. To view a copy of this licence, visit http://creativecommons.org/licen ses/by/4.0/.

\section{References}

Alden, Ch., and M. Schoeman. 2015. South Africa's symbolic hegemony in Africa. International Politics 52 (2): 239-254.

Amorim, C. 2014. Breves narrativas diplomáticas. Buenos Aires: Taeda.

Amorim, C. 2010. Brazilian Foreign Policy under president Lula (2003-2010): an overview. Revista Brasileira de Política Internacional 53 (special edition): 214-240.

Almeida, M.H.T., J. Onuki, and L.P. Carneiro. 2010. Brasil, as Américas e o Mundo: Opinão Pública e Política Externa. São Paulo: Instituto de Relações Internacionais, USP.

Braveboy-Wagner, J. 2016. Diplomatic Strategies of Nations in the Global South. The Search for Leadership. NewYork: Palgrave Macmillan.

Burges, S. 2017. Brazil in the World. The international relations of a South American giant. Manchester: Manchester University Press. 
Burges, S. 2018. Thinking through Brazil's Strategic Leadership Gap. In Regional Powers and Contested Leadership, ed. H. Ebert and D. Flemes, 63-84. New York: Palgrave Macmillan.

Burges, S., and F. Chagas Bastos. 2017. The importance of presidential leadership for Brazilian foreign policy. Policy Studies 38 (3): 277-290.

Cervo, A.L., and A.C. Lessa. 2014. O declínio: Inserção internacional do Brasil (2011-2014). Revista Brasileira De Política Internacional 57 (2): 133-151.

Chagas Bastos, F., and M. Franzoni. 2019. Frustrated Emergence? Brazil and Mexico's Coming of Age. Rising Powers Quarterly 4 (4): 33-59.

Cline, K., P. Rhamey, A. Henshaw, A. Sedziaka, A. Tandon, and T. Volgy. 2011. Identifying Regional Powers and Their Status. In Major Powers and the Quest for Status in International Politics: Global and Regional Perspectives, ed. T. Volgy, R. Corbetta, K. Grant, and R. Baird. New York: Palgrave MacMillan.

Destradi, S. 2010. Regional Powers and Their Strategies: Empire, Hegemony, and Leadership. Review of International Studies 36 (4): 903-930.

Destradi, S. 2017. Reluctance in international politics: A conceptualization. European Journal of International Relations 23 (2): 315-340.

Duque, M. 2018. Recognizing International Status: A Relational Approach. International Studies Quarterly 62 (1): 577-592.

Faria, C., D. Belem Lopes, and G. Casarões. 2013. Itamaraty on the Move: Institutional and Political Change in Brazilian Foreign Service under Lula da Silva's Presidency (2003-2010). Bulletin of Latin American Research 32 (4): 468-482.

Flemes, D., and R. Castro. 2016. Institutional Contestation: Colombia in the Pacific Alliance. Bulletin of Latin American Research 35 (1): 78-92.

Frazier, D., and R. Stewart-Ingersoll. 2010. Regional Powers and Security: A Framework for Understanding Order within Regional Security Complexes. European Journal of International Relations 16 (4): 731-753.

Fukuyama, F. 2014. The Foreign Policy Essay: The Domestic Basis of American Power. Lawfare https:// www.lawfareblog.com/foreign-policy-essay-domestic-basis-american-power

Gardini, G. 2016. Brazil: What Rise of What Power? Bulletin of Latin American Research 35 (1): 5-19.

Garzon, J. 2017. Multipolarity and the future of economic regionalism. International Theory 9 (1): 101-135.

Gilpin, R. 1981. War and Change in World Politics. Cambridge: Cambridge University Press.

Goertz, G. 2017. Multimethod Research, Causal Mechanisms, and Case Studies: An Integrated Approach. Princeton: Princeton University Press.

Guimaraes, F., and M. Maitano. 2019. Socializing Brazil into Regional Leadership: The 2006 Bolivian Gas Crisis and the Role of Small Powers in Promoting Master Roles Transitions. Foreign Policy Analysis 15 (1): 1-20.

Guimaraes, F., I. Fernandes, and G. Maldonado. 2020. Domestic Attitudes toward Regional Leadership: A Survey Experiment in Brazil. Foreign Policy Analysis 16 (1): 98-117.

Hoffmann, S. 1978. A view from at home: The perils of incoherence. Foreign Affairs 57 (3): 464-491.

Hofmann, S., B. Bravo, and S. Campbell. 2016. Investing in International Security: Rising Powers and Organizational Choices. Cambridge Review of International Affairs 29 (3): 831-851.

Huntington, S. 1999. The Lonely Superpower. Foreign Affairs 78 (2): 35-49.

Hurrell, A. 2006. Hegemony, Liberalism, and Global Order: What Space for Would-Be Great Powers. International Affairs 82 (1): 1-19.

Ikenberry, J. 1996. The Future of International Leadership. Political Science Quarterly 111 (3): 385-402.

Kalout, H., and M. Degaut. 2017. Brasil, um país em busca de uma grande estratégia. Relatório de Conjuntura No. 1, Brasilia: Secretaria Geral de Assuntos Estratégicos, Presidência da República.

Kitchen, N. 2010. Systemic pressures and domestic ideas: A neoclassical realist model of grand strategy formation. Review of International Studies 36 (1): 117-143.

Lake, D. 2007. Escape from the state of nature: Authority and hierarchy in world politics. International Security 32 (1): 47-79.

Larson, D., T.V. Paul, and W.C. Wohlforth. 2014. Status and world order. In Status in World Politics, ed. T.V. Paul, D. Larson, and W.C. Wohlforth. Cambridge: Cambridge University Press.

Lehmann, K. 2017. Can Brazil Lead? The Breakdown of Brazilian Foreign Policy and What it Means for the Region. Rising Powers Quarterly 2 (2): 125-147.

Lima, J. 2018. Latin America's Decentred Economic Regionalism: From the FTAA to the Pacific Alliance. Contexto Internacional 40 (2): 339-359. 
Malamud, A. 2011. A Leader Without Followers? The Growing Divergence between the Regional and Global Performance of Brazilian Foreign Policy. Latin American Politics and Society 53 (3): 1-24.

Malamud, A. 2017. Foreign Policy Retreat: Domestic and Systemic Causes of Brazil's International Rollback. Rising Powers Quarterly 2 (2): 149-168.

Mann, M. 1984. The Autonomous Power of the State. European Journal of Sociology 25 (2): 185-213.

Merke, F., D. Reynoso, and L. Schenoni. 2020. Foreign Policy Change in Latin America. Latin American Research Review 55 (3): 413-429.

Mijares, V. 2018. Performance of the South American Defense Council Under Autonomy Pressures. Latin American Policy 9 (2): 258-281.

Mitchelli, D. 2016. Regional Power? Yes, but What Kind? Paper Presented at International Studies Association Asia-Pacific, Hong Kong, June 25-27; http://web.isanet.org/Web/Conferences/AP\% 20Hong\%20Kong\%202016/Archive/a6e97a55-34b4-4b63-9f95-2b7c47f2a231.pdf

Monteiro, N. 2012. Unrest Assured: Why Unipolarity Is Not Peaceful. International Security 36 (3): $9-40$.

Moravcsik, A. 1997. Taking Preferences Seriously: A Liberal Theory of International Politics. International Organization 51 (4): 513-553.

Nolte, D. 2010. How to Compare Regional Powers: Analytical Concepts and Research Topics. Review of International Studies 36 (4): 881-901.

Onuki, J., F. Mouron, and F. Urdinez. 2016. Latin American Perceptions of Regional Identity and Leadership in Comparative Perspective. Contexto Internacional 38 (1): 433-465.

Prys, M. 2010. Hegemony, Domination, Detachment: Differences in Regional Powerhood. International Studies Review 12 (4): 479-504.

Renshon, J. 2016. Status Deficits and War. International Organization 70 (3): 513-550.

Ripsman, N.M., J.W. Taliaferro, and S.E. Lobell. 2016. Neoclassical Realist Theory of International Politics. New York: Oxford University Press.

Rivarola Puntigliano, A. 2008. Going Global: An organizational study of Brazilian foreign policy. Revista Braslileira De Politica Internacional 51 (1): 8-52.

Røren, P., and P. Beaumont. 2019. Grading greatness: Evaluating the status performance of the BRICS. Third World Quarterly 40 (3): 429-450.

Schenoni, L.L. 2012. As Possíveis Causas Domésticas da Liderança Brasileira na América do Sul. Contexto Internacional 34 (2): 659-691.

Schenoni, L.L. 2017. Subsystemic Unipolarities? Power Distribution and State Behaviour in South America and Southern Africa. Strategic Analysis 41 (1): 74-86.

Schenoni, L.L. 2021. Brazil: Pursuing the Multipolar Mirage. In National Perspectives on a Multipolar Order, ed. B. Zala. Manchester: Manchester University Press.

Schenoni, L.L., and C. Escudé. 2016. Peripheral Realism Revisited. Revista Brasileira De Política Internacional 59 (1): 1-18.

Schenoni, L.L., and D. Leiva. 2021. Dual Hegemony: Brazil Between the United States and China. In Hegemonic Transition, ed. F. Böller and W. Werner. London: Springer.

Schenoni L.L., BelemLopes D., Casaroes G. 2019. Myths of Multipolarity: The Sources of Brazilian Overexpansion. LSE-Global South Unit Working Paper Series, 5(1): 1-22.

Schirm, S.A. 2010. Leaders in Need of Followers: Emerging Powers in Global Governance. European Journal of International Relations 16 (2): 197-221.

Schoeman, M. 2003. South Africa as an Emerging Middle Power: 1994-2003. In State of the Nation: South Africa, ed. J. Daniel, A. Habib, and R. Southall, 2003-2004. Cape Town: HSRC Press.

Scholvin, S., and A. Malamud. 2020. Is Brazil a Geoeconomic Node? Brazilian Political Science Review 14 (2): 1-39.

Schulz, C. 2019. Hierarchy Salience and Social Action: Disentangling Class, Status, and Authority in World Politics. International Relations 33 (1): 88-108.

Schweller, R.L. 2006. Unanswered Threats. Political Constraints on the Balance of Power. Oxford: Oxford University Press.

Singer, J.D., and M. Small. 1966. The Composition and Status Ordering of the International System: 1815-1940. World Politics 18 (1): 236-282.

Spektor, M. 2016. Brazil: Shadows of the past and contested ambitions. In Shaper Nations: Strategies for a Changing World, ed. W.I. Hitchcock, M.F. Leffler, and J.W. Legro, 17-35. Cambridge: Harvard University Press.

Spektor, M. 2021. Strategies of rising Brazil: Postmortem review, looking forward. Contemporary Politics. https://doi.org/10.1080/13569775.2021.1961452. 
Stuenkel, O. 2014. Brazil's Diplomatic Retreat. Americas Quarterly, https://www.americasquarterly.org/ content/brazils-diplomatic-retreat

Stuenkel, O. 2019. How Bolsonaro's Chaotic Foreign Policy Worries the Rest of South America. Americas Quarterly, https://www.americasquarterly.org/content/bolsonaros-chaotic-foreign-policy

Taliaferro, J.W. 2009. Neoclasical realism and resource extraction: State building for future war. In Neoclassical Realism, the State and Foreign Policy, ed. S.E. Lobell, N.N. Ripsman, and J.W. Taliaferro. Cambridge: Cambridge University Press.

Tellis, A. J., J. Bially, Ch. Layne, and M. McPherson. 2000. Measuring National Power in the Postindustrial Age. Santa Monica: RAND Corporation.

Thies, C.G. 2001. A Social Psychological Approach to Enduring Rivalries. Political Psychology. 22 (4): 693-725.

Thies, C.G., and D. Nieman. 2018. Rising Powers and Foreign Policy Revisionism. Ann Arbor: University of Michigan Press.

Thies, C.G., and A.C. Sari. 2018. A Role Theory Approach to Middle Powers: Making Sense of Indonesia's Place in the International System. Contemporary Southeast Asia: A Journal of International and Strategic Affairs. 40 (3): 397-421.

Treverton, G., and S.G. Jones. 2005. Measuring National Power. Santa Monica: RAND Corporation.

Trubowitz, P., and P. Harris. 2019. The end of the American century? Slow erosion of the domestic sources. International Affairs 95 (3): 619-639.

Underdal, A. 1994. Leadership theory: Rediscovering the arts of management. In International multilateral negotiation: Approaches to the management of complexity, ed. I.W. Zartman. San Francisco: Jossey-Bass Publishers.

Urdinez, F., F. Mouron, A. Oliveira, and L.L. Schenoni. 2016. Chinese Economic Statecraft and US Hegemony in Latin America: An Empirical Analysis, 2003-2014. Latin American Politics and Society 58 (4): 3-30.

Vadell, J. A., and C. Giaccaglia. 2019. Brazil's Role in Latin American Regionalism. The Oxford Encyclopedia of Latin American Politics.

Vaz, A.C. 2018. Restraint and regional leadership after the PT Era: an empirical and conceptual assessment. Rising Powers Quarterly 3 (1): 25-43.

Volgy, T.J., and A. Bailin. 2003. International Politics and State Strength. Boulder and London: Lynne Rienner Publishers.

Volgy, T.J., P. Bezerra, J. Cramer, and J.P. Rhamey. 2017. The Case for Comparative Regional Analysis in International Politics. International Studies Review 19 (1): 452-480.

Walt, S.M. 2009. Alliances in a Unipolar World. World Politics 61 (1): 86-120.

Waltz, K. 1979. Theory of International Politics. New York: McGraw-Hill.

Wehner, L.E. 2015. Role Expectations As Foreign Policy: South American Secondary Powers' Expectations of Brazil As A Regional Power. Foreign Policy Analysis 11 (4): 435-455.

Wehner, L. E., and D. Nolte. 2017. Role Theory and Geopolitical Thinking in South America. In M. A. G. Suarez, R. Duarte Villa, and B. Weiffen (Eds.) Power Dynamics and Regional Security in Latin America. Basingstoke: Palgrave Macmillan.

Wigell, M. 2016. Conceptualizing regional powers' geoeconomic strategies: Neo-imperialism, neo-mercantilism, hegemony, and liberal institutionalism. Asia Europe Journal 14 (2): 135-151.

Wohlforth, W.C. 1999. The Stability of a Unipolar World. International Security 24 (1): 5-41.

Wohlforth, W.C., B. Carvalho, H. Leira, and I.B. Neumann. 2017. Moral authority and status in International Relations: Good states and the social dimension of status seeking. Review of International Studies 44 (3): 526-546.

Womack, B. 2016. Asymmetry in International Relationships. Cambridge: Cambridge University Press.

Zakaria, F. 1998. From Wealth to Power. Princeton: Princeton University Press.

Zanini, F. 2017. Euforia e Fracasso do Brasil Grande: Política Externa e Multinacionais Brasileiras na Era Lula. São Paulo: Contexto.

Publisher's Note Springer Nature remains neutral with regard to jurisdictional claims in published maps and institutional affiliations. 